Croatian Journal of Education

Vol.21; No.2/2019, pages: 479-510

Original research paper

Paper submitted: $15^{\text {th }}$ January 2018

Paper accepted: $31^{\text {st }}$ October 2018 https://doi.org/10.15516/cje.v21i2.3050

\title{
Teachers' Perceptions of Teaching English in Primary School: A Comparative Study between India and Slovenia
}

\author{
Mateja Dagarin Fojkar' and Katarina Kilibarda Perret ${ }^{2}$ \\ 'University of Ljubljana, Faculty of Education Department of Education Studies \\ ${ }^{2}$ InGlobEn Institute
}

\section{Abstract}

The paper analyses teachers' perceptions of teaching English in primary school in India and in Slovenia. Teachers are one of the key factors for successful foreign language instruction and, despite some contrary misconceptions, they need to meet high criteria to be qualified for teaching a foreign language to children. Therefore, we conducted a comparative study among 313 teachers of English, 143 Slovene teachers and 170 Indian teachers of English. The aims of our research were to investigate teachers' reasons for choosing a teaching career, task types teachers perform with their pupils, and teachers' attitudes towards developing pupils' English language skills. Furthermore, we wanted to explore their suggestions for improvements in teaching English in primary schools in India and Slovenia. A questionnaire with closed-type questions was designed and distributed among the teachers in both countries. Although the two countries vary immensely in size and the role of English, it is interesting to observe some similarities in teachers' perceptions of teaching English as a foreign or a second language, for example, the importance of developing speaking, listening and vocabulary in foreign language instruction, and the need for better access to resources. However, there are many differences in their perceptions, especially in the reasons for choosing a teaching career and task types they regularly use in their classes.

Key words: foreign language instruction; learners of English; school system; teacher training.

\section{Introduction}

Teachers are one of the key factors for successful foreign language instruction. Research shows that the quality of teachers and their teaching are the most important 
factors in student outcomes (OECD, 2005). With foreign languages being introduced earlier and earlier into the education system, the need for qualified teachers has spurred, and as many studies are reporting (e.g. Emery, 2012; Enever, 2015; Garton, Copland, \& Burns, 2011; Hayes, 2014; Murphy, 2014; Rixon, 2013), there is a wide gap between the supply of and the demand for them. Nikolov and Mihaljević Djigunović (2011) explain that teachers of young learners need to be proficient in both, children's first language and foreign language (from now on FL), as well as having an in-depth knowledge of the content and curriculum, and at the same time be experts in teaching young learners and teaching languages in particular. Cameron (2004) adds that they also need to have the skills and knowledge to conduct whole lessons orally and to teach FL initial literacy skills. Many teachers are unable to meet all these expectations. Butler (2004) has revealed there is a substantial gap between the English proficiency level of primary school teachers in some Asian countries and the level they need to teach. Emery (2012) found, in her extensive study, that there is considerable variation in contexts regarding teachers' qualifications and many of them have no qualifications to teach children or to teach a FL. Brumen, Lešnik, and Ivanuš Grmek (2017) claim that it is important to implement a uniform national policy regarding the teaching and learning of foreign languages and provide funds for continuous FL teacher training.

The authors of the present study wanted to investigate this area in more detail, comparing two countries, namely India and Slovenia. The two countries differ in many aspects; therefore, it would be intriguing to see how much the teachers' perceptions of their teaching vary or are related. Various areas of teaching have been researched; among others, teachers' attitudes towards foreign language teaching, their motivation for teaching, the activities they use in the classroom, and ways of improving teaching of FLs in their respective countries. The authors of the article have had substantial experience teaching in both countries and feel that their experience and teachers' views can give a relevant portrayal of the FL teaching practice at the primary level in these countries. In India, teaching has always been considered one of the noblest professions, stemming from religious teachers and preachers (Azam \& Kingdon, 2013), whereas in Slovenia the role of the teacher is gradually changing from a traditional, authoritative, 'know-all' type to a more multifaceted role of facilitator and tutor (Novak, 2005). The reasons for choosing a teaching career have been explored previously in both countries, showing that teachers in India often choose this profession because it offers respect and security (Manabi, 2001) and teachers in Slovenia often say they chose it because they 'like working with children' (Ivanuš Grmek \& Lačen, 2008). Different types of teacher motivation are closely related to teaching quality, engagement and commitment to select appropriate task for developing learners' skills (de Jesus \& Lens, 2005). Kyriacou and Coulthard (2000) distinguish between intrinsic, extrinsic and altruistic reasons for selecting the teaching profession. According to Deci and Ryan (2000), employees high in intrinsic motivation are more involved in their 
jobs, more self-driven, autonomous and persistent in their work. On the other hand, extrinsically motivated employees may not see any meaning in their jobs and have less persistence (Deci \& Ryan, 2000). Consequently, intrinsically motivated teachers pursue a teaching profession because they like working with children and want their pupils to learn effectively, whereas, teachers who are extrinsically motivated view teaching as a profession that provides extrinsic rewards, such as a good salary, better security, good career prospects and a higher status (Kyriacou \& Coulthard, 2000). Intrinsic motivation for teaching is tightly linked to the altruistic reasons for choosing a teaching profession, which are exhibited, for example, in teachers' wish to make a contribution to the society and to make a difference in children's lives (Moran, Kilpatrick, Abbot, Dallat, \& McClune, 2001). Different types of motivation thus influence strongly what the teacher does in the classroom and which learning areas the teacher emphasizes.

\section{Primary Education in India and in Slovenia School System}

Slovenia is a small country in southern Central Europe with approximately 2.06 million inhabitants. Slovene is its main language, with Italian and Hungarian as official minority languages. India, on the other hand, is a vast country with 1.2 billion inhabitants. Hindi and English are its two official languages and, according to the Eighth Schedule of the Constitution of India, there are 22 state languages (Rana, 2014). The Slovenian school system is centralised, meaning that all public primary schools follow the same programme and curriculum. India is made up of 35 states and its education system is decentralised and regulated at two levels: central and federal. Educational institutions differ regarding the level at which they operate (Rhines Cheney, Brown Ruzzi, \& Muralidharan, 2005). About 20\% of schools in India are private (ASER 2013), while in Slovenia there are only six private primary schools in the whole country, with less than $1 \%$ of pupils attending them (Statistični urad RS, 2017). There is a huge variety in the quality of public primary schools in India and as a result, the number of private schools is growing rapidly (Graddol, 2010). Despite their differences, the two countries share some common points. Both of them offer obligatory and free education and in both countries, children start school at the age of six. However, in Slovenia, primary education lasts 9 years, whereas in India it lasts 8 years. Although many European countries are facing a shortage of teachers, this problem is not present in Slovenia yet (Eurydice, 2013). The number of teachers in India is on the rise, due to the establishment of new schools and easier access to higher education (Nayar, 1982). There is a big difference in the number of pupils per teacher in these countries; in Slovenia there were on average 17 pupils per teacher in 2011, and in India there were 35 pupils per primary school teacher (Pupil-teacher ratio in primary education, n.d.). However, as Emery (2012) has found in her extensive study, Indian teachers may teach classes of more than 65 pupils. 


\section{Use of English}

English in India is one of the two official languages, whereas in Slovenia, it has a status of a foreign language. The reasons for its use differ from country to country. In India, English serves as a means of everyday communication due to the immense variety of mother tongues (Azam, Chin, \& Prakash, 2010), while in Slovenia it is used for communication with foreigners and for international business dealings. In India, English is now losing its status of a 'library language', used only for reading and writing, and spoken English is gaining more and more importance, though school curricula have not reflected this change yet (Graddol, 2010). In both countries, English increases employability, widens access to higher education and consequently provides a better economic state of an individual (cf. Graddol, 2010). Parents in both countries are aware of this fact and therefore try to include their children into private schools, or pay for their private language courses. The growth of the educational private sector in India is immense, especially the number of so-called 'English-medium schools' where English is the language of instruction and into which, as Mukund Ghatage (2009) reports, parents enrol their children even if they cannot afford the fees. While in Slovenia all schools offer the same number of lessons in English per year, there is a great variety in the amount of English instruction at schools in India. In India schools differ immensely according to the level at which they operate; private/public abiding by state, federal or local ministries of education (Education in India, 2014). In India, children officially start learning English in the $1^{\text {st }}$ grade (age 6), and in Slovenia the formal beginning is in the $2^{\text {nd }}$ grade, which commenced in the 2016/2017 school year. An experimental introduction of the obligatory first foreign language in the first grade (age 6) of the Slovenian primary school started in 2018/2019. In India there can be as many as 5 hours of English per week (Mukund Ghatage, 2009), whereas in Slovenia the number of primary school English lessons varies from two to four a week, depending on the year of learning (Učni načrt za angleščino, 2016). However, language proficiency of Slovene adults is higher than that of Indian adults. According to the English Proficiency Index (EF, 2015), Slovenia has achieved 64, 97\% (i.e. very high proficiency level) and has taken $6^{\text {th }}$ place among 70 countries taking part in the survey, whereas India has taken 20 th place with the result $58,21 \%$ (i.e. high proficiency).

\section{Teacher Training for Primary English Language Teaching}

As Emery (2012) reports, many countries around the world are experiencing a shortage of primary school English teachers. Consequently, schools employ teachers who are not fully trained to teach children or have inadequate knowledge of English. Many countries also increase the number of learners in a class, to solve this problem. As Graddol (2010) observes, this problem is even greater in India than in other countries, where classes already have many learners compared to other countries (see above). Therefore, there are plenty of teacher education programmes offered, which vary in quality and length of study. In the lower grades of primary school, a teacher who 
has finished a two-year teacher training programme can teach (Education in India, 2014). English can be taught by any qualified primary school teacher without taking any special courses in English (Education in India, 2014). Low levels of qualification can be observed in the Indian Teacher Eligibility Test (TET), which is a mandatory test for obtaining and retaining a teaching position in state schools, namely the tests executed in 2011 were passed by fewer than $10 \%$ of teachers (Education in India, 2014). Mukund Ghatage (2009) furthermore reports that teachers are not confident in their use of English; they feel they lack the knowledge of English grammar and think their pronunciation may be inaccurate. As a result, they do not want to use English in their lessons. Graddol (2010, p. 15) warns that this shortage of English teachers in India will create "inequality of provision and inequality of learning outcomes".

In Slovenia, all primary school teachers are required to have a master's degree and, altogether, their teacher education lasts five years. Primary teachers, who wish to teach English, need to specialise in teaching English, and the courses include developing their language skills as well as their knowledge of methodology of teaching English to children (Brumen \& Dagarin Fojkar, 2012). As in other countries, there is a shortage of primary school English teachers as English is introduced earlier in the primary education curriculum. This problem is being tackled by pre-service as well as in-service teacher training programmes, which offer approximately 660 hours of additional FL training (Brumen \& Dagarin Fojkar, 2012). In Slovenia, English in primary school can be taught by a primary school teacher with special training in FL teaching to children (they can teach up to grade 6, i.e. age 11) or a language specialist, who needs to have additional training in teaching children if they want to teach in the first three grades of primary school.

It is agreed by foreign language teaching experts that teacher education is of extreme importance in primary education, and we can concur with Hayes (2014), who states that for the long term benefit, initial or pre-service training has to be at the heart of successful primary English teaching.

\section{Methodology}

The main aim of the research was to investigate the differences and similarities between Slovenian and Indian teachers' perceptions of teaching English in primary school.

The research questions of the study were as follows:

1. Is there a difference between Indian and Slovenian teachers regarding the reasons why they chose a teaching career?

2. Are there differences in the types and frequencies of activities teachers use in teaching English in Slovenia and in India?

3. Are there differences in the teachers' attitudes towards developing pupils' English language skills in Slovenia and India?

4. Are there differences in the teachers' beliefs of how to improve English language teaching and learning in their own countries? 
On the basis of the research questions, the following hypotheses were formed:

1. Indian and Slovenian primary school teachers of English differ significantly in the reasons for choosing the teaching career.

2. There are differences in the types and frequencies of activities teachers use in teaching English in primary schools in Slovenia and India.

3. Teachers in India and in Slovenia differ in their attitudes towards developing primary pupils' English language skills.

4. Teachers in India and Slovenia differ in their beliefs about the changes needed to improve the level of English language learning and teaching in their respective countries.

\section{Participants}

Altogether 313 teachers took part in the research (170 from India and 143 from Slovenia). These were mostly female teachers with a slightly higher number of male teachers in India (33 male teachers in India and 9 male teachers in Slovenia). Their average age was 36 years and they had up to 10 years of teaching experience on average ( 0 - 4 years: $28.5 \%$, and $5-9$ years: $34.1 \%)$. There is a difference in the average number of students per class between the two countries, namely, in India the surveyed teachers report that the average number of the students in their classroom is $36-50$ students and in Slovenia there are $16-20$ students per class. The starting age of learning English at schools, where the surveyed teachers worked at the time of the study, was 4 in India and 9 in Slovenia. However, in Slovenia the obligatory starting age lowered in 2016/2017 to 7 years of age (2nd grade).

\section{Research Instruments and Data Collection}

The study was conducted in the form of an anonymous questionnaire, measuring teachers' perceptions of their teaching of English in the two selected countries. An online questionnaire was used in Slovenia, through the electronic survey tool $w w w$. mojaanketa.si and a hard copy of the questionnaires was used in India, due to limited or no technological access. In Slovenia, email invitations for an online questionnaire were sent to primary school teachers of English from different regions of Slovenia. In India, the head teachers of primary schools in the city of Varanasi (Uttar Pradesh) were visited, the aim of the research was explained to them and the hard copy questionnaires were given to them, which they distributed among the teachers of English. Thus, the type of sampling in the research was non-probability, opportunity sampling. The research took place from January to June 2014. The questionnaire comprised of closed-type questions. The survey was divided into four elements characteristic of primary English teachers' practices, which were (a) reasons for choosing a teaching career, (b) typical activities performed in the classroom and their frequency, (c) development of their pupils' English language skills and (d) ways of improving the English language instruction at schools in India and Slovenia. To investigate the reasons for choosing a teaching career, the teachers had to select one reason out of 
11 given reasons, i.e. 'it's a good career,' 'I like children', 'it's a respectable job,' it offers secure employment,' 'you have long holidays', 'it has a good salary', 'there are good chances of promotion', 'you have a short workday,' 'you have good chances of getting a job,' 'the training was easy', 'someone recommended teaching as a career.' The reasons were taken from the most often selected reasons of 2,478 primary English teachers from 89 countries (Emery, 2012). The variables for the second research question (activities teachers use in teaching English) were measured on a frequency rating scale of their usage ( 5 - every lesson, 4 - often, 3 - sometimes, 2 - rarely, 1 - never). Teachers had to rate the following 20 activities for teaching English: copying from the blackboard, drama, creative activities, translation, ICT activities, watching video clips, grammar exercises, creative writing, spelling, dictation, teacher telling stories, learning words by heart, singing, repeating after the teacher, role play, silent reading, listening to audio tapes, pupils telling stories, games, group work. The activities were slightly adapted from Garton, Copland, and Burns' study (2011) of the most common English language teaching activities of 4,696 teachers from 144 countries. A ranking scale from 1 to 6 ( 1 - most important, 6 - least important to develop) was used for measuring the teachers' perceptions of the most important language skills to develop in their pupils (reading, listening, speaking, writing, vocabulary or grammar). The variables were selected according to the division of the language skills in foreign language teaching (Ur, 2012). A similar division of language skills is applied in Garton et al. (2011). A ranking scale from 1 to 8 (1 - most important, i.e. it would improve teaching and learning in my setting the most and 8 - least important, i.e. it would improve teaching and learning in my setting the least) was used for measuring the factors that teachers perceive would improve their teaching. Teachers ranked the following eight factors: smaller classes; starting English at an earlier age; more lessons of English per week; additional training in language teaching methodologies; better access to new technologies; better access to resources, i.e. books and materials; fewer tests and examinations; improvement in their own level of English. The factors were accessed from Garton et al's extensive study (2011). All survey items were mostly based on literature review of global prevailing practices in primary English language teaching (Emery, 2012; Garton et al., 2011). Furthermore, the authors had had extensive conversations with some of the teachers in both countries, regarding their practices, which were used as a further source for the selection of the variables. The survey items were then piloted with seven potential respondents in each country. The questions were adapted according to the pilot study. Beside the literature review and the piloting, content validity of the instrument was assessed with the help of three subject-matter experts, who were asked to provide feedback on the questionnaire and how well the questions measure the construct. Objectivity was ensured with the selection of the closed-type questions. In view of the research questions, mainly descriptive (absolute frequency, percent, mean, standard deviation) procedures and statistical tests (Pearson's chi-square test with adjusted standardised residual) were applied, using the statistical package SPSS, version 21.0. 


\section{Results}

Figure 1 shows the main reasons why Slovenian and Indian teachers decided to become English language teachers. Most teachers in Slovenia chose a teaching career because they like working with children (50.8\%), whereas this reason was chosen only by $29 \%$ of the Indian teachers of English. They mostly decided on a teaching career because it is a respectable profession (32.6\%), which was chosen only by $6.1 \%$ of Slovenian teachers. Similarly, the surveyed teachers from India chose a teaching profession because it is perceived as a good career $(24.6 \%)$ and only $3.9 \%$ of Slovenian teachers of English chose this reason. In addition, $14.5 \%$ of Slovenian and $4.2 \%$ of the Indian teachers in the survey decided to become teachers because it offers secure employment. All other reasons received low percentages in both countries (e.g. you have long holidays: $3 \%$ in Slovenia and 1\% in India, it has a good salary: $0.5 \%$ in Slovenia and 1.5\% in India, there are good chances of promotion: $5 \%$ in Slovenia and $0.2 \%$ in India, you have a short workday: $2.2 \%$ in Slovenia and $2.6 \%$ in India; you have good chances of getting a job: $7.3 \%$ in Slovenia, $1.3 \%$ in India; the training was easy: $1.8 \%$ in Slovenia and $0.5 \%$ in India, someone recommended teaching as a career: $3.9 \%$ in Slovenia and $0.5 \%$ in India). We can see that teachers in India and Slovenia differ in their selection of reasons for becoming teachers. Further analysis showed that most of these differences are statistically significant.

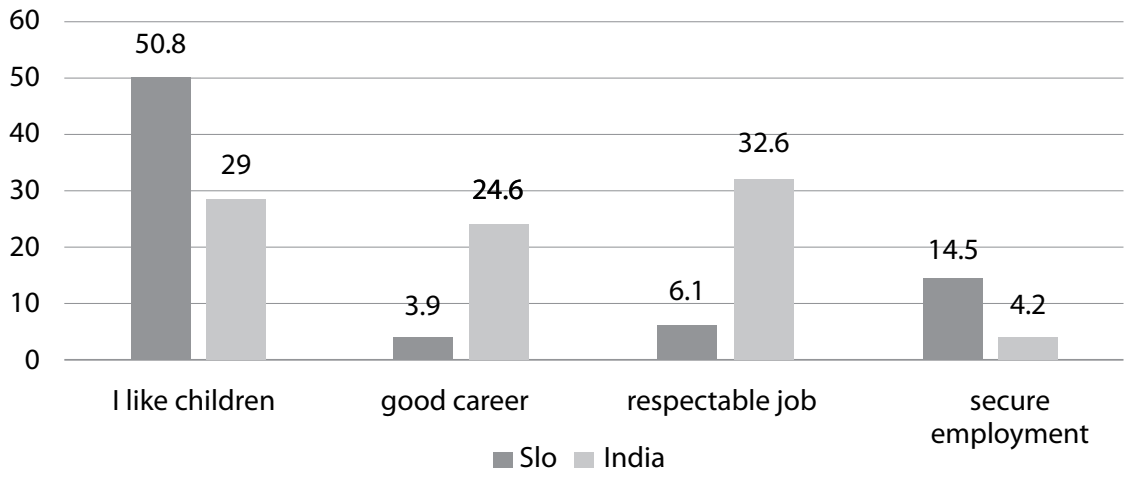

Figure 1. Teachers' main reasons for choosing a teaching career

Table 1

Pearson's correlations among the variables

\begin{tabular}{ccccc}
\hline $\begin{array}{c}\text { Main reasons for } \\
\text { becoming teachers }\end{array}$ & $\begin{array}{c}\text { India } \\
\mathrm{f}(\mathrm{f} \%)\end{array}$ & $\begin{array}{c}\text { Slovenia } \\
\mathrm{f}(\mathrm{f} \%)\end{array}$ & $\begin{array}{c}\text { value } \\
\mathrm{X}^{2}\end{array}$ & $\begin{array}{c}\text { Asymp. Sig. } \\
\text { (2-sided) } \\
\mathrm{P}\end{array}$ \\
\hline I like children & $50(29 \%)$ & $73(50.8 \%)$ & 8.389 & 0.004 \\
Secure employment & $8(4.2 \%)$ & $21(14.5 \%)$ & 2.916 & 0.088 \\
Respectable job & $56(32.6 \%)$ & $9(6.1 \%)$ & 197.7 & 0.000 \\
Good career & $42(24.6 \%)$ & $6(3.9 \%)$ & 124.09 & 0.000 \\
\hline
\end{tabular}


Figure 2 below displays the most common activities teachers of English use in their primary classes. They classified the activities according to how often they use them (5 - every lesson, 4 - often, 3 - sometimes, 2 - rarely, 1 - never).

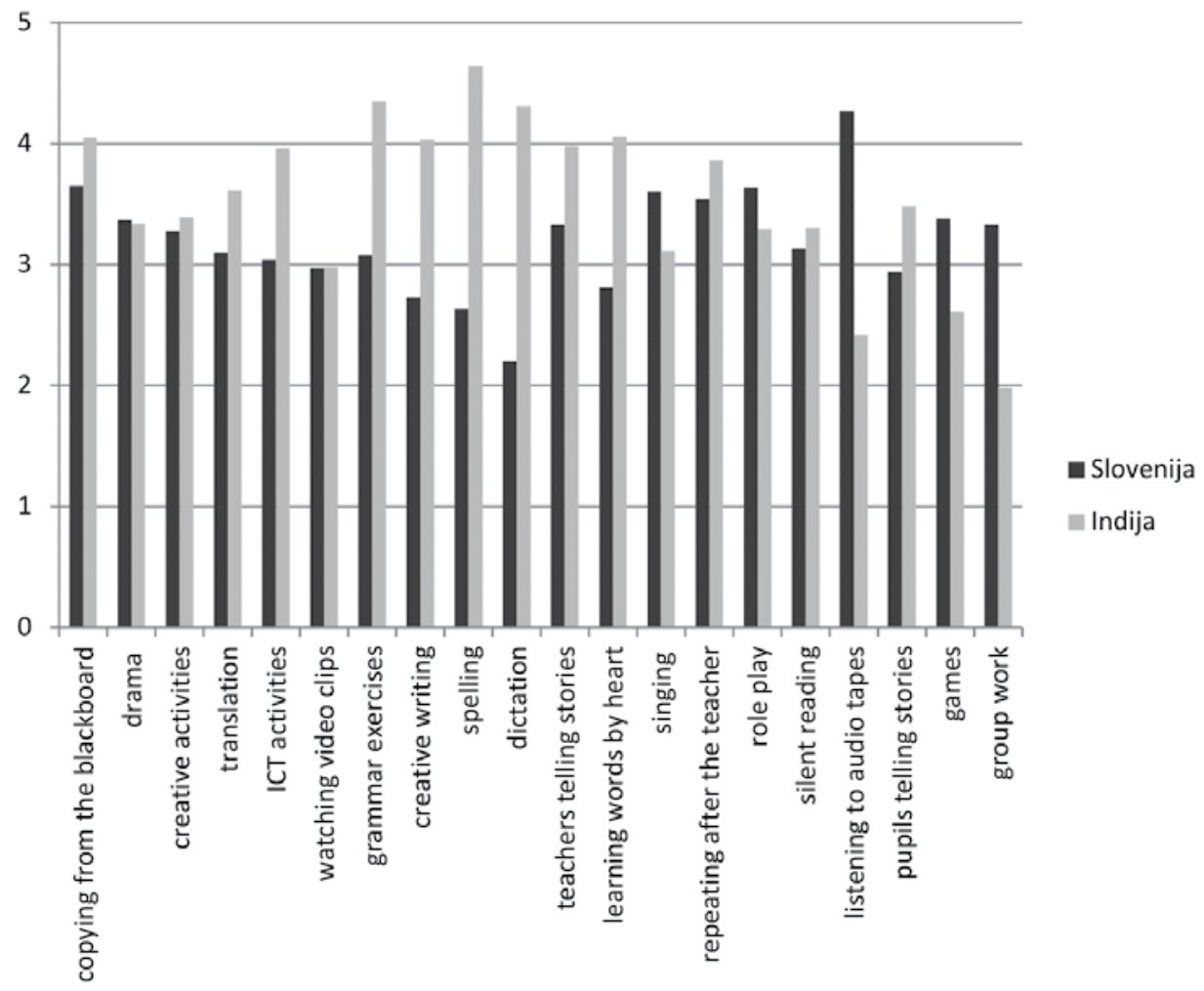

Figure 2. Frequency of activities teachers use in teaching

Some of the activities that prevail in the Indian lessons of English are spelling activities, grammar exercises, dictation, learning words by heart and copying from the blackboard. Activities that are often present in the Slovenian classrooms of English are listening to audio tapes, copying from the blackboard, singing, role plays, games, repeating after the teacher, group work and drama activities. The main gap between India and Slovenia is shown in these activities; whereas the surveyed English teachers in India mostly focus their work on reading and writing, the English teachers in Slovenia concentrate on developing listening and speaking skills in their lessons. However, the surveyed teachers in India often use creative writing activities, which are used only from time to time in Slovenian classes. 


\section{Importance of different skills}

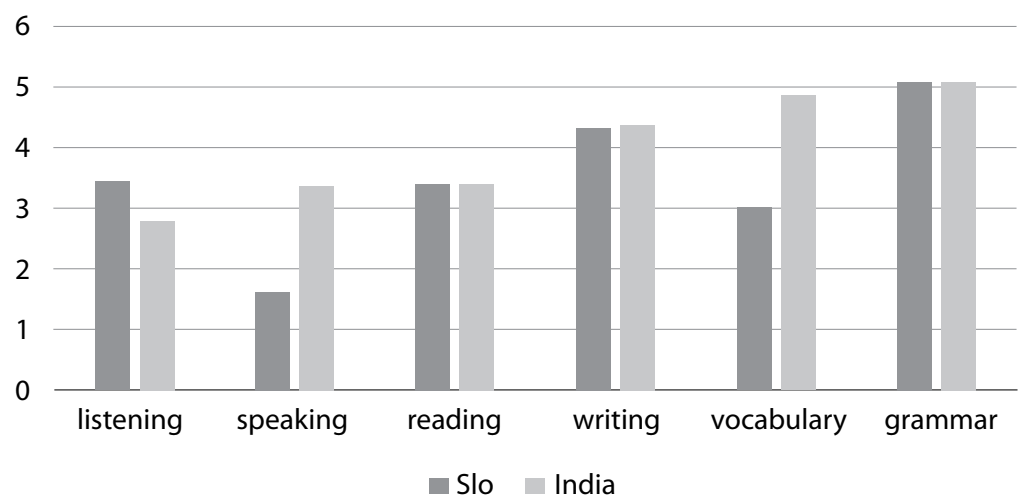

Figure 3. Importance of developing different skills in teaching English at the primary level

Figure 3 shows the skills the surveyed teachers in both countries found the most important to develop in their primary English classes. Teachers needed to classify the skills (listening, speaking, reading, writing, vocabulary and grammar) in the order of importance from 1 to 6 ( 1 - most important, 6 - least important). We can see that Slovenian teachers think speaking is the skill that needs to be practised the most in English lessons, and grammar is the one that needs to be practised the least. The surveyed teachers in India agree with the skill that needs to be practised the least (i.e. grammar), but they have chosen the development of the listening skill as the most important. Slovenian teachers put much more emphasis on the development of vocabulary, compared to their counterparts in India. Teachers in both countries placed the development of reading and writing skills on the same level (reading has reached medium importance and developing writing is perceived as not so important in primary English classes). Table 2 below summarises the statistic data for the linguistic skills that the Indian and the Slovenian teachers selected as the most important to develop with their pupils.

Table 2

Descriptive statistics for the importance of different skills in teaching English at the primary level

\begin{tabular}{llrrrrrr}
\hline Country & & speaking & vocab. & reading & listening & writing & grammar \\
\hline Slovenia & Mean & 1.636 & 3.035 & 3.448 & 3.455 & 4.343 & 5.084 \\
& $\mathrm{~N}$ & 143 & 143 & 143 & 143 & 143 & 143 \\
& $\mathrm{SD}$ & 1.110 & 1.469 & 1.117 & 1.5732 & 1.364 & 1.297 \\
\multirow{3}{*}{ India } & Mean & 3.394 & 4.876 & 3.424 & 2.794 & 4.406 & 5.076 \\
& $\mathrm{~N}$ & 170 & 170 & 170 & 170 & 170 & 170 \\
& $\mathrm{SD}$ & 1.965 & 1.862 & 1.652 & 2.0494 & 1.742 & 1.800 \\
\hline
\end{tabular}




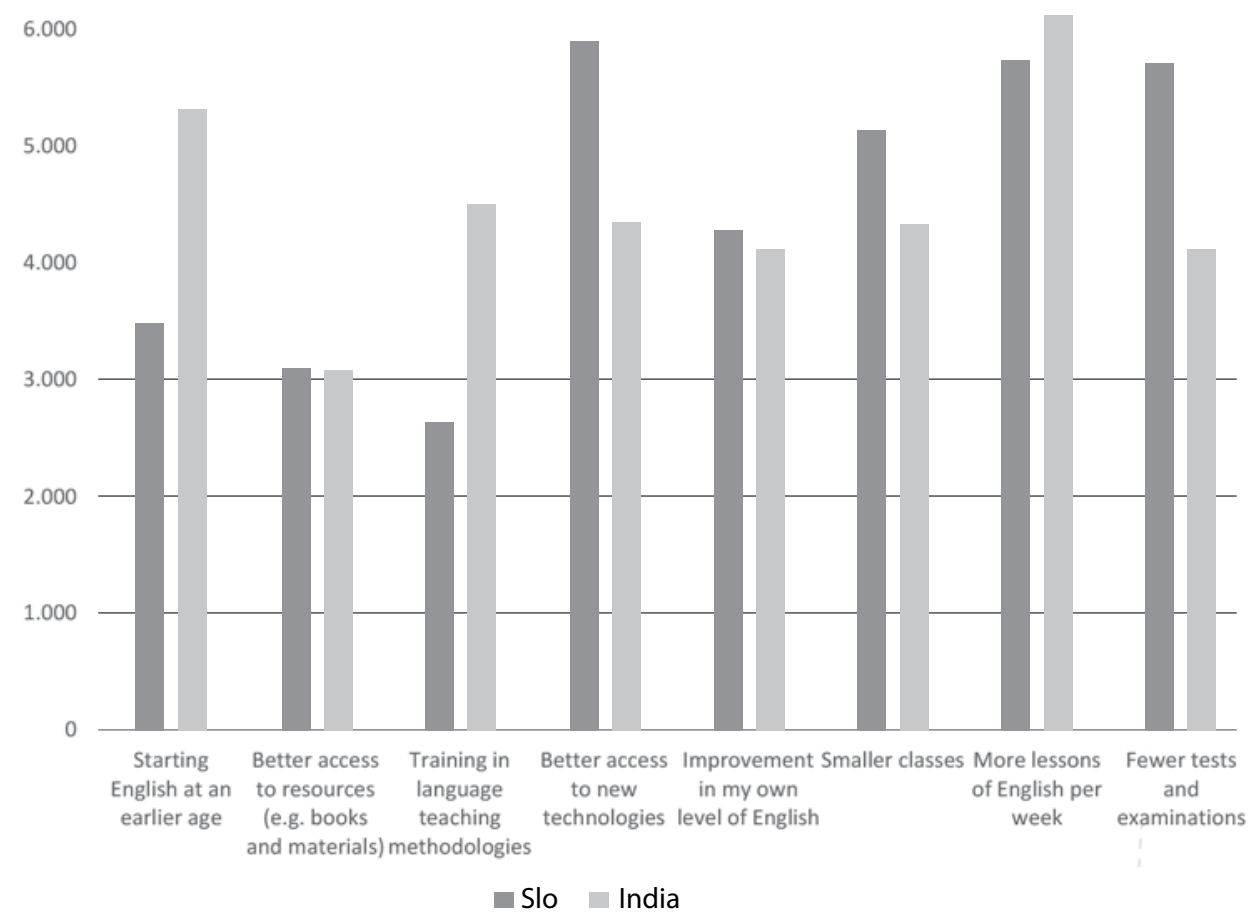

Figure 4. Changes needed to improve learning and teaching

Figure 4 shows some of the factors which teachers believe would improve their English classes. Teachers were asked to order eight factors according to their importance (1 - most important, i.e. it would improve teaching and learning in my setting the most and 8 - least important, i.e. it would improve teaching and learning in my setting the least). The teachers could choose among the following factors: smaller classes, starting English at an earlier age, more lessons of English per week, additional training in language teaching methodologies, better access to new technologies, better access to resources, i.e. books and materials, fewer tests and examinations, and improvement in my own level of English. Again, many differences between the two countries can be observed. Slovenian teachers ranked a higher level of importance (compared to Indian teachers) to starting English at an earlier age and the training in language teaching methodologies. Whereas Indian teachers, compared to Slovenians, ranked a higher level of importance to better access to new technologies and fewer tests and examinations. Better access to resources (e.g. books and materials) achieved a high level of importance in both countries. 
Table 3

Descriptive statistics for the changes needed to improve English language teaching and learning

\begin{tabular}{|c|c|c|c|c|c|c|c|c|c|}
\hline country & & $\begin{array}{l}\text { Starting } \\
\text { English at } \\
\text { an earlier } \\
\text { age }\end{array}$ & $\begin{array}{c}\text { Better access } \\
\text { to resources } \\
\text { (e.g. } \\
\text { books and } \\
\text { materials) }\end{array}$ & $\begin{array}{l}\text { Training in } \\
\text { language } \\
\text { teaching } \\
\text { methodologies }\end{array}$ & $\begin{array}{l}\text { Better access } \\
\text { to new } \\
\text { technologies }\end{array}$ & $\begin{array}{l}\text { Improvement } \\
\text { in my own } \\
\text { level of } \\
\text { English }\end{array}$ & $\begin{array}{c}\text { Smaller } \\
\text { classes }\end{array}$ & $\begin{array}{l}\text { More } \\
\text { lessons } \\
\text { of } \\
\text { English } \\
\text { per } \\
\text { week }\end{array}$ & $\begin{array}{c}\text { Fewer } \\
\text { tests and } \\
\text { examinations }\end{array}$ \\
\hline \multirow{3}{*}{ Slovenia } & Mean & 3.476 & 3.098 & 2.636 & 5.902 & 4.280 & 5.154 & 5.741 & 5.713 \\
\hline & $\mathrm{N}$ & 143 & 143 & 143 & 143 & 143 & 143 & 143 & 143 \\
\hline & SD & 2.006 & 2.114 & 1.852 & 2.046 & 1.832 & 1.812 & 2.071 & 1.794 \\
\hline \multirow{3}{*}{ India } & Mean & 5.329 & 3.088 & 4.512 & 4.353 & 4.129 & 4.335 & 6.129 & 4.124 \\
\hline & $\mathrm{N}$ & 170 & 170 & 170 & 170 & 170 & 170 & 170 & 170 \\
\hline & $S D$ & 2.183 & 2.449 & 2.235 & 2.362 & 2.102 & 1.924 & 1.749 & 2.006 \\
\hline
\end{tabular}

\section{Discussion}

Regarding the first research question (i.e. Is there a difference between Indian and Slovenian teachers regarding the reasons why they chose a teaching career?), we can see that teachers in both countries selected the teaching career for different reasons. Slovene teachers mainly chose it because they like children and Indian teachers chose it mainly because it is a respectable job. This is also reported in other documents, e.g. the Ministry of Human Resource Development (n.d.) states that a teaching profession in India is highly respected. This can also be the reason why more and more Indian students decide to become teachers, and in the growth of private institutions that offer teacher training certificates (Rhines Cheney, Brown Ruzzi, \& Muralidharan, 2005). In Emery's study (2012), which included 2500 primary English teachers from different parts of the world, most teachers (77\%) chose the same reason as the Slovenian teachers, i.e. because they like children, whereas $29 \%$ of them chose it because it is a respectable job. Apparently, these two reasons are among the most common ones in other parts of the world as well. It is interesting to observe that the main reason selected by the Indian teachers is of the extrinsic nature and the main reason selected by the Slovenian teachers is of the intrinsic nature. Bernaus, Wilson, and Gardner (2009) report the result of a study which suggests that teacher motivation is related to teacher use of motivating strategies, which in turn are related to student motivation and achievement in English language. Therefore, any change in the educational system that promotes higher levels of teacher motivation should result in improved levels of education of the students. In accordance with that, more intrinsically motivated teachers will be more self-driven and autonomous in their work and selection of teaching activities. The first hypothesis has thus been proven, namely, Indian and Slovenian primary school teachers of English differ significantly in the reasons for choosing the teaching career. 
The second research question explored the differences in the types and frequencies of activities teachers use in their teaching of English. Again, there are many differences in the use of activities. The most striking one is the difference in focusing on oral and listening work in Slovenian primary lessons of English and reading and writing activities (with spelling, dictation and grammar exercising prevailing) in Indian classes. The English syllabi for primary school in Slovenia encourage the development of listening and speaking in the first years of learning a foreign language and as can be seen from the present survey, the teachers are following the syllabi in this respect (Učni načrti za angleščino, 2016). Mukund Ghatage (2009) reports that teachers in the Indian state of Maharashtra are encouraged by the government documents to focus on listening and speaking skills in primary schools, but at the same time notices that teachers in rural areas do not have access to audio materials and that teachers do not often use English in class, both of which results in a lack of development of students' listening and speaking skills. Despite the fact that the teachers focus on developing reading and writing skills, Kunnan and Matthew (2006) as well as Azam and Kingdon (2013) assessed Indian primary students' reading and writing skills, and they noticed that they were not as well developed as they should have been. Banerji and Bobde (2013) summarise ASER report (2013) stating that less than half the children in grade 5 can read simple words in English and $40 \%$ of those who can read words are not able to tell their meaning. Studies also show that teachers in India concentrate on developing grammar, despite the government recommendations that the focus in teaching should be more on meaning than grammar (NCERT, 2006). The situation was similar in Slovenia in the past, but the latest national syllabuses for English strongly encourage communicative language teaching (Skela, 2013). Garton et al. (2011) in their survey of classroom practices in primary school English language teaching worldwide (4,696 teachers from 144 countries) reported that the five most used classroom activities are: repeating after the teacher, listening to audio tapes, pupils reading aloud, playing games and singing songs. In the present survey, these activities are more common in Slovenia than India. The second hypothesis, i.e. 'There are differences in the types and frequencies of activities teachers use in teaching English in primary schools in Slovenia and India' can be proven.

Regarding the third research question (i.e. Are there differences in the teachers' attitudes towards developing pupils' English language skills in Slovenia and India?), the study showed some differences in teachers' perceptions of the importance of skills. While Slovenian teachers deemed the development of English speaking skills (mean: 1.63) and vocabulary (3.03) as the most important, Indian teachers considered developing pupils' listening (mean: 2.79) and speaking skills (mean: 3.39 ) as the most important, which is interesting, since the activities they use in their teaching (see Figure 2) depict a tendency towards developing reading and writing skills. Garton et al.s study (2011) showed similar results; primary English teachers worldwide consider speaking (mean 2.4) as the most important skill to be developed in primary 
classes, with listening (mean 3.1) and vocabulary (mean 3.6) following. Comparably to the present study, they perceive grammar and writing as the least important skills to be developed in primary instruction. The third hypothesis, 'Teachers in India and in Slovenia differ in their attitudes towards developing primary pupils' English language skills' can be partly proven. Teachers mostly differ in their perception of the importance of developing vocabulary and speaking skill, but their views as far as the development of grammar, reading and writing skill is concerned, are quite similar.

In the fourth research question where teachers were asked about the factors that would improve English language teaching in their countries, the Slovenian teachers chose starting English at an earlier age as an important factor. This can be assigned to the fact that at the time of the survey, English was introduced in the fourth grade (now it starts in the second grade) and therefore this was perceived as an important factor for the teachers. This is not perceived as an important factor in India, since English is taught from the $1^{\text {st }}$ grade onwards. Due to the fact that English is taught at an earlier age which requires a different teaching paradigm compared to teaching older learners, Slovenian teachers chose training in language teaching methodologies as the most important factor that would contribute to better English language teaching and learning in Slovenia. Teaching a foreign language in the first years of primary school requires autonomous teachers who can select and create their own materials for teaching and not choose a course book, which is, in fact, discouraged in the first years of learning a FL in Slovenian schools. Similarly, Enever (2015) claims that despite the lack of materials, skilled teachers can still perform high quality lessons, creating their own materials and adapting materials that they have.

Most of the factors that would improve learning and teaching of foreign languages in India differ from the Slovenian ones. The only factor that is very similar is better access to resources, which is perceived by Indian teachers as the most important one. As reported in other studies (e.g. Kapur, 2009; Matthew \& Pani, 2009) there is a lack of materials in Indian classes, which the authors see as resulting in lower quality of instruction. The surveyed teachers from India chose improvement in their own level of English as the second most important factor. It is noted in many sources (Graddol, 2010; Kapur, 2009; Mukund Ghatage, 2009, among others) that Indian teachers of English lack fluency in English and that their overall proficiency is often low. Apparently, the teachers are aware of this fact and its importance in teaching foreign languages. Indian teachers chose fewer tests and examinations as the third most important factor which derives from the fact that there is pressure on teachers regarding assessment procedures and pupils' results in Indian classes. The fourth selected factor is smaller classes, which is self-explanatory, since the average number of students in a classroom is, according to the World Bank data, 35 but can exceed 90 students (Pupil-teacher ratio in primary education, n.d.). The results from Garton et al's study (2011) of 4,696 teachers from 144 countries showed that primary school teachers worldwide chose training in language teaching methodology, smaller classes 
and more hours of English per week as the most important factors that would improve English language instruction in their countries. Some of these factors overlap with the results from our study, except more hours of English per week, which gained a low level of importance in raising the quality of FL learning and teaching among the surveyed Slovenian and Indian primary teachers of English. The last hypothesis, 'Teachers in India and Slovenia differ in their beliefs about the changes needed to improve the level of English language learning and teaching in their respective countries' can be proven, most of the changes needed to improve learning and teaching differ.

\section{Conclusions}

The present study attempted to shed light on the perceptions of primary school teachers of English in two countries, namely India and Slovenia. We believe that these findings can help teachers, teacher educators and course planners in evaluating current FL teaching and learning contexts, and in designing future courses for teachers of foreign languages. The results have shown some of the differences between the two groups of surveyed teachers, mostly in the choice of a teaching profession, which most of the Slovenian teachers chose because they like children (coinciding with the previous research done by Garton et al., 2011), and most Indian teachers chose it because it is a respectable job. The fact that Slovenian teachers' reasons for choosing a teaching profession are of an intrinsic nature and the surveyed Indian teachers' reasons are extrinsic can be related to the other results of the survey, namely the differences in activities they use in their teaching, the choice of the language skills they wish to develop in their learners and the factors they believe would improve their own teaching. However, there are also some similarities between the Indian and Slovenian teachers' perceptions of FL teaching that have surfaced from the study, for example in choosing speaking, listening and vocabulary as the most important skills that their pupils need to develop in FL learning, which again relates to the opinions of other teachers worldwide (Garton et al., 2011). Slovenian and Indian teachers also agreed on the importance of the factor that would improve FL learning and teaching in their countries, which is better access to resources.

Nevertheless, a comparison between the two surveyed countries brings potential pitfalls, since English in Slovenia is a foreign language and in India, it has a status of an official language. Teachers in India need to be well trained to meet the needs of their learners, who want to have a high level of knowledge to improve their career prospects. This may be the reason why they chose the improvement of their own level of English as the second most important change that would contribute to a better level of English learning in their country. The skills they want to develop the most in their learners (listening, speaking and reading) can benefit their learners in everyday communication and in business transactions.

We acknowledge that the sample of our research was not representative and thus it is not possible to generalise the results, however, the study results can imply some 
of primary English teachers' perceptions. Another limitation of the study is that the survey results represent reported practices that may not always coincide with the actual practices, so further research should include classroom observations and more in-depth analysis of the reported practices.

Hayes (2014, p. 2) states that the most important element influencing success in teaching English in primary schools is that "teachers who have positive attitudes towards English and teaching the language [will] influence children's motivation to learn, their enjoyment of their English classes and, ultimately, their achievement". Future studies on the current topic are therefore required in order to examine teachers' perceptions and ways of improving the education of teachers, their level of foreign language skills and teaching methodologies, which will result in pupils' higher level of foreign language proficiency and a wish to continue with lifelong learning of languages.

\section{References}

ASER 2013 - Rural: Annual Status of Education Report. (2013). Retrieved from http://img. asercentre.org/docs/Publications/ASER\%20Reports/ASER 2013/ASER2013 report\%20 sections/aser2013fullreportenglish.pdf

Azam, M., Chin, A., \& Prakash, N. (2010). The return to English-Language skills in India (discussion paper). Bonn: IZZA. Retrieved from http://www.uh.edu/ achin/research/ azam chin prakash.pdf

Azam, M., \& Kingdon, G. G. (2013). Assessing Teacher Quality in India. IZA Discussion Paper, 8622. University of London: London. https://doi.org/10.2139/ssrn.2512933

Banerji, R., \& Bobde, S. (2013). Evolution of the ASER English tool. In V. Berry (Ed.), English Impact Report: Investigating English Language Learning Outcomes at the Primary School Level in Rural India (pp. 27-33). London: British Council.

Bernaus, M., Wilson, A., \& Gardner, R. C. (2009). Teachers' motivation, classroom strategy use, students' motivation and second language achievement. Porta Linguarum, 12, 25-36.

Brumen, M., \& Dagarin Fojkar, M. (2012). Teacher development in Slovenia for teaching foreign languages at the primary level. CEPS Journal, 2(3), 27-53.

Brumen, M., Lešnik, S., \& Ivanuš Grmek, M. (2017). Domestic Encouragement for Young Foreign Language Learners in Slovenia. Croatian Journal of Education: Hrvatski časopis za odgoj i obrazovanje, 19(2), 337-362. https://doi.org/10.15516/cje.v19i2.1989

Butler, Y. G. (2004). What level of English proficiency do elementary teachers need to attain to teach EFL? Case studies from Korea, Taiwan, and Japan. TESOL Quarterly, 38, 245-287. https://doi.org/10.2307/3588380

Cameron, L. (2004). Challenges in ELT from the expansion in teaching children. ELT Journal, 57, 9-16. https://doi.org/10.1093/elt/57.2.105 
Constitution of India. (n.d.). Retrieved from http://india.gov.in/sites/upload_files/npi/files/ coi-eng-schedules 1-12.pdf

Deci, E. L., \& Ryan, R. M. (2000). The "what" and "why" of goal pursuits: Human needs and the self-determination of behavior. Psychological Inquiry, 11, 227-268. https://doi. org/10.1207/S15327965PLI1104 01

De Jesus, S. N., \& Lens, W. (2005). An integrated model for the study of teacher motivation. Applied Psychology: An International Review, 54, 119-134. https://doi.org/10.1111/j.1464$\underline{0597.2005 .00199 . x}$

Education in India. (2011). Retrieved from http://prayatna.typepad.com/education/2011/11/ teacher-eligibility-test-for-school-teachers.html

EF - English Proficiency Index. (2015). Retrieved from http://www.ef.com/epi/

Emery, H. (2012). A Global Study of Primary English Teachers' Qualification, Training and Career Development. London: British Council.

Enever, J. (2015). The advantages and disadvantages of English as a foreign language with young learners. In J. Bland (Ed.), Teaching English to Young Learners (pp. 13-31). London: Bloomsbury.

Eurydice: Key Data on Teachers and School Leaders in Europe (2013). Brussels: European Commission.

Garton, S., Copland F., \& Burns, A. (2011). Investigating Global Practices in Teaching English to Young Learners. London: British Council.

Graddol, D. (2010). English Next India. Delhi: British Council.

Hayes, D. (2014). Factors Influencing Success in Teaching English in State Primary Schools. London: British Council.

Ivanuš-Grmek, M., \& Lačen, I. (2008). Razlogi študentov za izbiro poklica učitelj razrednega pouka [Students' reasons for choosing a primary school teaching profession]. Revija $z a$ elementarno izobraževanje, 1(1/2), 87-94.

Kapur, K. (2009). Teaching English at the Primary Level in India: An overview. In J. Enever, J. Moon, \& U. Raman (Eds.), Young Learner English Language Policy and Implementation: International Perspectives (pp. 79 - 87). Reading, UK: Garnet Education.

Kunnan, A. J., \& Matthew, R. (2006). English language exams reform project in India: From achievement to proficiency testing. Paper presented at the Language Testing Research Colloquium, Melbourne.

Kyriacou, C., \& Coulthard, M. (2000). Undergraduates' views of teaching as a career choice. Journal of Education for Teaching: International Research and Pedagogy, 26(2), 117-126. https://doi.org/10.1080/02607470050127036

Manabi, M. (2001). Educational Opportunities in Rajasthan and Tamil Nadu: Despair and Hope. In A. Vaidyanathan, \& P. R. Gopinathan Nair (Eds.), Elementary Education in Rural India - A Grassroots View (pp. 320-394). New Delhi: Sage Publications.

Mathew, R., \& Pani, S. (2009). Issues in the Implementation of Teaching English for Young Learners (TEYL): A case study of two states in India. In J. Enever, J. Moon, \& U. Raman (Eds.), Young Learner English Language Policy and Implementation: International Perspectives (pp. 113 - 121). Reading, UK: Garnet Education. 
Dagarin Fojkar and Kilibarda Perret: Teachers' Perceptions of Teaching English in Primary School ...

Ministry of Human Resource Development. Government of India. (n.d.). Retrieved from http:// mhrd.gov.in/

Moran, A., Kilpatrick, R., Abbot, L., Dallat, J., \& McClune, B. (2001). Training to teach: Motivating factors and implication for recruitment. Evaluation \& Research in Education, 15(1), 17-32. https://doi.org/10.1080/09500790108666980

Mukund Ghatage, M. (2009). Introduction of English from Grade 1 in Maharashtra, India. In J. Enever, J. Moon, \& U. Raman (Eds.), Young Learner English Language Policy and Implementation: International Perspectives (pp. 45 - 53). Reading, UK: Garnet Education.

Murphy, V. A. (2014). Second Language Learning in the Early School Years: Trends and Contexts. Oxford: OUP.

National Curriculum Framework (2005). New Delhi: National Council of Educational Research and Training.

National Council of Educational Research and Training (NCERT). (2006). National Focus Group on Teaching of English. Position Paper (pp. 1 - 18). New Delhi, India: NCERT.

Nayar, P. K. B. (1982). Sociology in India, Retrospect \& Prospect. Delhi: B.R.Publ.Corp.

Nikolov, M., \& Mihaljević Djigunović, J. (2011). All shades of every color: an overview of early teaching and learning of foreign languages. Annual Review of Applied Linguistics, 31, 95-119. https://doi.org/10.1017/S0267190511000183

Novak, M. (2005). Vloga učitelja $v$ devetletni osnovni šoli [The role of the teacher in a nine-year primary school]. Nova Gorica: Melior.

OECD. Organisation for Economic Co-operation and Development. (2005). Teachers matter: Attracting, developing, and retaining effective teachers. Paris: OECD.

Pupil-teacher ratio in primary education. (n.d.). Retrieved from http://data.worldbank.org/ indicator/SE.PRM.ENRL.TC.ZS

Rana, S. (2014). A Brief Study of Language Specified in Schedule VIII of the Indian Constitution. Express, an International Journal of Multi Disciplinary Research, 1(6), 1-12. Retrieved from http://express-journal.com/pdf/June14Issue6/ ABriefStudyofLanguageSpecifiedinScheduleVIIIoftheIndianConstitution.pdf

Rhines Cheney, G., Brown Ruzzi, B., \& Muralidharan, K. (2005). A profile of the Indian Education System. Washington: National Center on Education and the Economy.

Rixon, S. (2013). British Council Survey of Policy and Practice in Primary English Language Teaching Worldwide. London: British Council.

Skela, J. (2013). A Retrospective View of English Language Learning Materials Produced in Slovenia from 1945 to the Present. ELOPE: English Language Overseas Perspectives and Enquiries, 10(2), 97-124. https://doi.org/10.4312/elope.10.2.97-124

Statistični urad Republike Slovenije [Statistical Office of the Republic of Slovenia]. (2017). Retrieved from http://www.stat.si/tema_demografsko_prebivalstvo.asp

Učni načrti za angleščino [English Language Syllabi]. (2016). Retrieved from http://www.mizs. gov.si/fileadmin/mizs.gov.si/pageuploads/podrocje/os/prenovljeni_UN/UN_anglescina. pdf.

Ur, P. (2012). A Course in English Language Teaching (2 ${ }^{\text {nd }}$ ed.). Cambridge: Cambridge University Press. 


\section{Mateja Dagarin Fojkar}

University of Ljubljana, Faculty of Education,

Department of Education Studies

Kardeljeva pl. 16, 1000 Ljubljana, Slovenia

mateja.dagarin@pef.uni-lj.si

\section{Katarina Kilibarda Perret}

InGlobEn Institute

Rua Eduardo 453, 02371 São Paulo, Brazil

katarina.kilibarda@gmail.com 


\section{Percepcije učitelja o poučavanju engleskoga jezika u osnovnoj školi: komparativno istraživanje između Indije i Slovenije}

\section{Sažetak}

U radu se analiziraju percepcije učitelja o poučavanju engleskoga jezika u osnovnoj školi u Indiji i Sloveniji. Učitelji čine jedan od ključnih faktora za uspješno poučavanje stranoga jezika $i$, unatoč nekim suprotnim zabludama, moraju udovoljiti visokim kriterijima koji ih kvalificiraju za poučavanje stranoga jezika djeci. Zbog toga smo proveli komparativno istraživanje među 313 učitelja engleskoga jezika od kojih su 143 učitelja iz Slovenije, a 170 ih je iz Indije. Ciljevi našega istraživanja bili su ispitati učitelje u vezi s razlozima odabira profesije učitelja, vrstama aktivnosti koje učitelji provode sa svojim učenicima, kao i sa stavovima učitelja prema razvijanju jezičnih vještina iz engleskoga jezika kod učenika. Nadalje, željeli smo istražiti njihove prijedloge vezane uz poboljšanja u poučavanju engleskoga jezika u osnovnoj školi u Indiji i Sloveniji. Za potrebe istraživanja izrađen je upitnik s pitanjima zatvorenoga tipa koji je bio podijeljen učiteljima u obje zemlje. Iako se spomenute zemlje uvelike razlikuju u veličini, a i u ulozi engleskoga jezika, interesantna je pojavnost sličnosti u percepciji učitelja o poučavanju engleskoga kao stranoga ili drugoga jezika, primjerice u važnosti razvoja vještina govorenja, slušanja i vokabulara u poučavanju stranoga jezika, kao i želji za boljem pristupu resursima. Međutim, postoje mnoge razlike u njihovim percepcijama, posebice u razlozima odabira učiteljske profesije i vrstama aktivnosti koje redovito imaju u svojim razredima.

Ključne riječi: osposobljavanje učitelja; poučavanje stranoga jezika; školski sustav; učenici engleskoga jezika.

\section{Uvod}

Učitelji su jedni od ključnih čimbenika uspješnoga poučavanja stranoga jezika. Istraživanja pokazuju da je kvaliteta učitelja i njihovo obrazovanje jedan od najvažnijih čimbenika učeničkih postignuća (OECD, 2005). Sa sve ranijim uvođenjem stranih jezika u obrazovni sustav, potaknuta je potreba za kvalificiranim učiteljima. Kako pokazuju rezultati mnogih istraživanja (vidi Emery, 2012; Enever, 2015; Garton, 
Copland i Burns, 2011; Hayes, 2014; Murphy, 2014; Rixon, 2013), postoji velik jaz u ponudi i potražnji takvih učitelja. Nikolov i Mihaljević Djigunović (2011) objašnjavaju da učitelji u ranome učenju moraju imati znanja iz djetetova materinskoga jezika $i$ stranoga jezika (SJ), kao i opširno znanje sadržaja i kurikula te u isto vrijeme biti stručnjaci u poučavanju djece mlađega školskoga uzrasta i poučavanju jezika. Cameron (2004) dodaje da također trebaju imati vještine i znanja kako bi mogli voditi cijeli nastavni sat i poučavati inicijalne vještine pismenosti na SJ. Mnogi učitelji ne mogu zadovoljiti sva ta očekivanja. Butler (2004) je otkrio kako postoji značajan jaz između razine jezičnoga znanja učitelja engleskoga jezika u nekim azijskim državama i razine koju trebaju poučavati. U svome opsežnome istraživanju Emery (2012) je pokazala da postoji značajna razlika u kontekstu kvalifikacija učitelja te da mnogi od njih nemaju kvalifikacije za poučavanje djece ili za poučavanje SJ. Brumen, Lešnik i Ivanuš Grmek (2017) smatraju da je važno implementirati istovrsnu nacionalnu politiku vezanu uz poučavanje i učenje stranih jezika te osigurati sredstva za kontinuirano obrazovanje učitelja stranih jezika.

Autori ovoga istraživanja htjeli su detaljnije istražiti to područje uspoređujući dvije zemlje, Indiju i Sloveniju. Spomenute zemlje razlikuju su u mnogočemu; stoga bi bilo zanimljivo vidjeti koliko se percepcije učitelja o poučavanju razlikuju ili su povezane. Istražena su različita područja poučavanja, među ostalima i stavovi učitelja stranih jezika, njihova motivacija za poučavanjem, razredne aktivnosti, načini na koje se poučavanje stranoga jezika u vlastitim zemljama može poboljšati. Autori ovoga rada imaju veliko iskustvo u poučavanju u obje zemlje te smatraju da njihovo iskustvo $\mathrm{i}$ pogledi učitelja daju važnu sliku o poučavanju stranoga jezika na osnovnoškolskoj razini u navedenim zemljama. U Indiji se poučavanje smatralo plemenitim poslom koji potiče od religijskih učitelja i propovjednika (Azam i Kingdon, 2013), a u Sloveniji se uloga učitelja postupno mijenjala od tradicionalne, autoritativne, „sveznajuće”, do višestrane uloge moderatora i tutora (Novak, 2005). Razlozi za odabir učiteljske profesije istraživani su u obje zemlje i pokazuju da učitelji u Indiji često odabiru učiteljsku profesiju jer je cijenjena i nudi sigurnost (Manabi, 2001) a učitelji u Sloveniji često kažu da su se odlučili na tu profesiju jer „,vole raditi s djecom” (Ivanuš Grmek i Lačen, 2008). Različiti oblici motivacije učitelja tijesno su povezani s kvalitetom poučavanja, angažmana i predanosti za odabir odgovarajućih aktivnosti koje razvijaju vještine učenika (de Jesus i Lens, 2005). Kyriacou i Coulthard (2000) razlikuju intrinzične, ekstrinzične i altruistične razloge za odabir učiteljske profesije. Prema Deci i Ryan (2000) zaposlenici s visokom intrinzičnom motivacijom više su uključeni u posao, imaju jači poriv te su autonomni i uporni u poslu. $S$ druge strane, moguće je da ekstrinzično motivirani zaposlenici ne vide smisao u svome poslu i manje su uporni (Deci i Ryan, 2000). Posljedica toga je da motivirani nastavnici obavljaju učiteljsku profesiju jer vole raditi s djecom i žele da učenici učinkovito uče, a ekstrinzično motivirani nastavnici poučavanje vide kao profesiju koja im daje ekstrinzične nagrade poput dobre plaće, veće sigurnosti, dobrih karijernih izgleda i većega statusa (Kyriacou 
i Coulthard, 2000). Intrinzična motivacija kod poučavanja je tijesno povezana s altruističnim razlozima za odabir učiteljske profesije, a vide se kod nastavnikove želje da doprinese društvu i da učini razliku u dječjim životima (Moran, Kilpatrick, Abbot, Dallat i McClune, 2001). Različiti tipovi motivacije jako utječu na to što učitelj radi u razredu i na koja će područja učenja staviti veći naglasak.

\section{Osnovnoškolsko obrazovanje u Indiji i Sloveniji Školski sustav}

Slovenija je mala država u južnom dijelu srednje Europe s otprilike 2,06 milijuna stanovnika. Slovenski je glavni jezik, a talijanski i mađarski službeni su manjinski jezici. $\mathrm{Za}$ razliku od Slovenije, Indija je velika zemlja s 1,2 milijarde stanovnika. Hindski i engleski su dva službena jezika i prema Osmom rasporedu ustava Indije postoje 22 državna jezika (Rana, 2014). Slovenski obrazovnu sustav je centraliziran, što znači da sve javne osnovne škole prate isti program i kurikul. Indiju čini 35 saveznih država, a obrazovni sustav je decentraliziran i reguliran u dvije razine; centralni i savezni. Obrazovne institucije razlikuju se s obzirom na razinu na kojoj djeluju (Rhines Cheney, Brown Ruzzi i Muralidharan, 2005). Otprilike 20\% škola u Indiji je privatno (ASER 2013), a u Sloveniji imamo samo šest privatnih osnovnih škola u cijeloj zemlji s otprilike $1 \%$ učenika koje ih pohađaju (Statistični urad RS, 2017). Velika je raznolikost u kvaliteti javnih osnovnih škola u Indiji, a rezultat toga je brzi rast broja privatnih škola (Graddol, 2010). Unatoč razlikama te dvije države imaju neke zajedničke točke. Obje nude obvezno i besplatno obrazovanje te u obje zemlje djeca kreću u školu u dobi od šest godina. Međutim, osnovnoškolsko obrazovanje u Sloveniji traje 9 godina, a u Indiji 8 godina. Iako se mnoge europske zemlje suočavaju s nedostatkom učitelja, taj problem nije do sada zabilježen u Sloveniji (Eurydice, 2013). Broj učitelja u Indiji se povećava zbog osnivanja novih škola i lakše dostupnosti visokome obrazovanju (Nayar, 1982). Među spomenutim zemljama postoji velika razlika u broju učenika po nastavniku; u Sloveniji je 2011. godine učitelj u prosjeku imao 17 učenika, a u Indiji je to 35 učenika po učitelju u osnovnoj školi (Pupil-teacher ratio in primary education, n.d.). Međutim, prema opsežnom istraživanju koji je provela Emery (2012), učitelji u Indiji mogu poučavati i razrede s više od 65 učenika.

\section{Uporaba engleskoga jezika}

Engleski jezik jedan je od dva službena jezika u Indiji, a u Sloveniji ima status stranoga jezika. Razlozi za uporabu engleskoga jezika razlikuju se od zemlje do zemlje. U Indiji se engleski koristi kao jezik svakodnevne komunikacije s obzirom na brojnost materinskih jezika (Azam, Chin i Prakash, 2010), a u Sloveniji se koristi za komunikaciju sa strancima i u međunarodnim poslovima. U Indiji engleski trenutno gubi status ,jezika knjižnice”, koji se koristi samo za čitanje i pisanje, a govorni engleski dobiva na važnosti, iako u školskim kurikulima ta promjena još nije evidentirana (Graddol, 2010). U obje zemlje engleski jezik omogućuje bolju zapošljivost, širu 
dostupnost visokom obrazovanju i omogućuje bolji ekonomski status pojedinca (Cf. Graddol, 2010). U obje zemlje roditelji su svjesni te činjenice i stoga pokušavaju uključiti svoju djecu u privatne škole ili platiti privatne sate jezika. Rast privatnoga sektora u obrazovanju u Indiji je neizmjeran, posebno takozvane „Škole na engleskome jeziku" gdje je engleski jezik jezik poučavanja i u koje, prema Mukund Ghatage (2009) roditelji upisuju svoju djecu čak i ako si ne mogu priuštiti školarine. U Sloveniji sve škole nude isti godišnji broj sati engleskoga jezika, a u Indiji postoje velike razlike u školama s obzirom na broj sati nastave na engleskome jeziku. U Indiji se škole razlikuju s obzirom na razinu na kojoj djeluju; privatne/javne koje pripadaju državnim, saveznim ili lokalnim ministarstvima obrazovanja (Education in India, 2014). U Indiji djeca službeno počinju učiti engleski jezik u prvome razredu (6 godina), a u Sloveniji je od školske godine 2016./2017. službeni početak učenja jezika drugi razred. Eksperimentalno uvođenje obveznog prvog stranog jezika u prvi razred (6 godina) u osnovne škole u Sloveniji započelo je 2018./2019. U Indiji je moguće izvođenje do 5 sati nastave engleskoga jezika tjedno (Mukund Ghatage, 2009), a u Sloveniji je broj sati nastave engleskoga jezika između dva i četiri sata tjedno, ovisno o godini učenja (Učni načrt za angleččino, 2016). Međutim, jezična znanja odraslih osoba u Sloveniji viša su od znanja odraslih osoba u Indiji. Prema English Proficiency Index (EF, 2015) Slovenija je ostvarila 64,97\% (odnosno vrlo visoku razinu znanja) te je zauzela 6 . mjesto među 70 zemalja koje su sudjelovale u istraživanju, a Indija je zauzela 20. mjesto $\mathrm{s}$ rezultatom $58,21 \%$ (odnosno, visoko znanje).

\section{Obrazovanje učitelja za poučavanje engleskoga jezika u osnovnoj školi}

Prema izvješću Emery (2012) mnoge zemlje u svijetu suočavaju se s nedostatkom učitelja engleskoga jezika u primarnom obrazovanju. Posljedica toga je da škole zapošljavaju učitelje koji nisu u potpunosti kvalificirani za poučavanje djece ili imaju nedovoljno znanje engleskoga jezika. Kako bi se taj problem riješio, mnoge zemlje također povećavaju broj učenika u razredu. Graddol (2010) zapaža da je taj problem veći u Indiji nego u drugim zemljama jer razredi u startu imaju više učenika u usporedbi s drugim zemljama (vidi gore). Stoga postoje mnogi programi za obrazovanje učitelja, ali oni variraju u kvaliteti i dužini trajanja. Učitelj koji je završio dvogodišnji program obrazovanja učitelja, može poučavati u nižim razredima osnovne škole (Education in India, 2014). Engleski može poučavati samo kvalificirani učitelj primarnoga obrazovanja bez slušanja posebnih kolegija na engleskome jeziku (Education in India, 2014). Niže razine kvalifikacije također se mogu zamijetiti u indijskom testu podobnosti za učitelje Indian Teacher Eligibility Test (TET), što je obavezni test za dobivanje i zadržavanje radnoga mjesta učitelja u državnim školama. Test koji je proveden 2011. godine prošlo je manje od 10\% učitelja (Education in India, 2014). Nadalje, Mukund Ghatage (2009) izvješćuje da učitelji nemaju sigurnost u služenju engleskim jezikom; osjećaju nedostatak znanja gramatike te smatraju da 
im je izgovor netočan. Zbog toga se oni ne žele koristiti engleskim jezikom u nastavi. Graddol (2010, str. 15) upozorava da takav nedostatak učitelja engleskoga jezika u Indiji može dovesti do „nejednakosti u provedbi i nejednakosti u ishodima učenja”.

U Sloveniji svi učitelji u osnovnoj školi moraju imati stupanj magistra, a obrazovanje učitelja traje pet godina. Učitelji u primarnom obrazovanju koji žele poučavati engleski jezik moraju se specijalizirati za poučavanje engleskoga, a kolegiji su usmjereni na razvoj jezičnih vještina, kao i na poznavanje metodike poučavanja engleskoga jezika u ranom učenju (Brumen i Dagarin Fojkar, 2012). Kao i u drugim zemljama, vidljiv je nedostatak učitelja engleskoga jezika u osnovnoj školi jer se engleski jezik uvodi sve ranije u kurikul za primarno obrazovanje. Taj problem rješava se programima za obrazovanje budućih učitelja i programima stručnoga usavršavanja koji nude otprilike 660 sati dodatnog obrazovanja u stranome jeziku (Brumen i Dagarin Fojkar, 2012). U Sloveniji engleski jezik u osnovnoj školi mogu poučavati učitelji primarnoga obrazovanja koji su prošli poseban program obrazovanja za poučavanje stranoga jezika u ranome učenju (oni mogu poučavati do šestoga razreda, tj. do uzrasta od 11 godina), ili jezični stručnjaci koji moraju steći dodatno obrazovanje za poučavanje djece ako žele poučavati u prva tri razreda primarnoga obrazovanja.

Postoji suglasnost među stručnjacima za poučavanje stranoga jezika da je obrazovanje učitelja iznimno važno u primarnom obrazovanju te zaključujemo s tvrdnjom da je za dugoročnu korist inicijalno obrazovanje učitelja središnja točka za uspješno poučavanje engleskoga jezika u primarnome obrazovanju (Hayes, 2014).

\section{Metodologija}

Glavni cilj istraživanja bio je proučiti razlike i sličnosti u percepciji poučavanja engleskoga jezika između slovenskih i indijskih učitelja.

Postavljena su sljedeća istraživačka pitanja:

1. Postoji li razlika između indijskih i slovenskih učitelja s obzirom na razloge zbog kojih su se odlučili na učiteljsku profesiju?

2. Postoje li razlike u vrstama i učestalosti aktivnosti kojima se učitelji koriste u poučavanju engleskoga jezika u Sloveniji i u Indiji?

3. Postoje li razlike u stavovima učitelja prema razvoju jezičnih vještina učenika u Sloveniji i u Indiji?

4. Postoje li razlike u uvjerenjima učitelja o načinu na koji se može poboljšati poučavanje i učenje engleskoga jezika u njihovim zemljama?

$\mathrm{Na}$ osnovi istraživačkih pitanja postavljene su sljedeće hipoteze:

1. Indijski i slovenski učitelji engleskoga jezika u primarnom obrazovanju značajno se razlikuju s obzirom na razloge odabira učiteljske profesije.

2. Postoje razlike u vrstama i učestalosti aktivnosti kojima se učitelji koriste $\mathrm{u}$ poučavanju engleskoga jezika u osnovnoj školi u Sloveniji i Indiji.

3. Učitelji u Indiji i Sloveniji razlikuju se u stavovima prema razvoju vještina engleskoga jezika kod učenika. 
4. Učitelji u Indiji i Sloveniji razlikuju se u stavovima o promjenama koje su potrebne za poboljšanje razine poučavanja i učenja engleskoga jezika u vlastitim zemljama.

\section{Ispitanici}

U istraživanju je sudjelovalo ukupno 313 učitelja (170 iz Indije i 143 iz Slovenije). Uzorak su činile većinom ispitanice te nešto veći broj muškaraca u Indiji (33 učitelja u Indiji i 9 učitelja u Sloveniji). Njihova prosječna dob bila je 36 godina i u prosjeku su imali do 10 godina radnoga iskustva u poučavanju ( 0 - 4 godine: $28,5 \%$, i 5 - 9 godina: $34,1 \%$ ). Postoji razlika u prosječnom broju učenika po razredu u te dvije zemlje. U Indiji učitelji izvješćuju da je prosječan broj učenika po razredu 36 - 50, a u Sloveniji 16 - 20 učenika po razredu. Početna dob za učenje engleskoga jezika u školama u kojima su radili ispitanici bila je 4 godine u Indiji i 9 godina u Sloveniji. Međutim, obvezno poučavanje engleskoga jezika u školi je u Sloveniji u 2016./2017. godini spušteno na 7 godina (drugi razred).

\section{Instrument i prikupljanje podataka}

Istraživanje je provedeno s pomoću anonimnog upitnika sa svrhom mjerenja percepcije učitelja o njihovu poučavanju engleskoga jezika u dvije spomenute zemlje. Online upitnik koristio se u Sloveniji putem alata za elektroničko anketiranje $w w w$. mojaanketa.si, a u Indiji se, zbog ograničenog pristupa tehnologiji, koristila tiskana inačica upitnika. Elektroničko pozivno pismo za sudjelovanjem u online upitniku poslano je učiteljima engleskoga jezika u primarnom obrazovanju iz različitih regija u Sloveniji. U Indiji su posjećeni ravnatelji osnovnih škola u gradu Varanasi (Uttar Pradesh) s ciljem objašnjavanja istraživanja i davanja tiskanih upitnika koje su oni distribuirali učiteljima engleskoga. Stoga vrsta uzorkovanja u ovome istraživanju nije bila slučajna nego prigodna. Istraživanje je provedeno od siječnja do lipnja 2014. Upitnik je sadržavao pitanja zatvorenoga tipa. Anketa je bila podijeljena prema četiri elementa djelovanja učitelja engleskoga jezika u osnovnom obrazovanju, odnosno (a) razlozi za odabir učiteljske profesije, (b) tipične aktivnosti koje provodi u razredu i njihova učestalost, (c) razvoj jezičnih vještina učenika u engleskome jeziku i (d) načini poboljšanja poučavanja engleskoga jezika u Indiji i Sloveniji. Za istraživanje razloga za odabir učiteljske profesije učitelji su morali izabrati jedan od 11 navedenih razloga, tj. ,, to je dobra profesija”, ,volim djecu”, ,posao je ugledan”, ,nudi siguran posao”, ,imaš duge praznike”, „plaća je dobra”, „dobre su mogućnosti napredovanja”, „kratak radni dan”, ,,dobre su mogućnosti dobivanja posla”, ,obuka nije teška”, ,netko mi je preporučio tu profesiju". Navedeni razlozi su prikupljeni iz 89 zemalja (Emery, 2012). Varijable za drugo istraživačko pitanje (aktivnosti kojima se učitelji koriste u poučavanju engleskoga) mjerene su na skali učestalosti korištenja (5 - svaki sati, 4 - često, 3 ponekad, 2 - rijetko, 1 - nikada). Učitelji su morali ocijeniti sljedećih 20 aktivnosti za poučavanje engleskoga jezika: prepisivanje s ploče, drama, kreativne aktivnosti, 
prijevod, IKT aktivnosti, gledanje videoisječaka, gramatičke vježbe, kreativno pisanje, pravopis, pričanje priča (učitelj), igranje uloga, čitanje u sebi, slušanje audiozapisa, pričanje priča (učenici), igre, rad u grupama. Aktivnosti su neznatno prilagođene iz izvora Garton, Copland i Burns (2011), koji navode najčešće aktivnosti za poučavanje engleskoga jezika, a koje su navela 4696 učitelja iz 144 zemlje. Ljestvica od 1 do 6 (1najvažnije, 6 - najmanje važno za razvoj) koristila se za mjerenje percepcije učitelja o najvažnijim jezičnim vještinama koje trebaju razviti njihovi učenici (čitanje, slušanje, govorenje, pisanje, vokabular ili gramatika). Varijable su odabrane s obzirom na podjelu jezičnih vještina u poučavanju stranih jezika (Ur, 2012). Sličnom podjelom jezičnih vještina koristili su se i Garton, Copland i Burns (2011). Ljestvica od 1 - 8 (1 najvažnije, tj. Najviše bi poboljšalo poučavanje i učenje u mojem okruženju i 8 - najmanje važno, tj. Najmanje bi poboljšalo učenje i poučavanje u mojem okruženju) koristila se za mjerenje čimbenika za koje učitelji smatraju da bi poboljšali poučavanje. Učitelji su rangirali sljedećih osam čimbenika: manji razredi; poučavanje engleskoga jezika od ranije dobi; više sati engleskoga jezika u tjednu; dodatno obrazovanje u metodici poučavanja jezika; bolji pristup novim tehnologijama; bolji pristup resursima, odnosno knjigama i materijalima; manje testova $i$ ispita; poboljšanje vlastite razine znanja engleskoga jezika. Čimbenike smo preuzeli iz istraživanja koje su proveli Garton, Copland i Burns (2011). Sve čestice u istraživanju uglavnom su bile zasnovane na pregledu literature vezane uz dominantne aktivnosti u poučavanju engleskoga jezika diljem svijeta (Emery, 2012; Garton, Copland i Burns, 2011). Nadalje, autori su imali opsežne razgovore s nekim učiteljima iz obje zemlje u vezi s njihovim poučavanjem koji su služili za dodatni izvor kod odabira varijabli. Čestice iz ankete pilotirane su na sedam potencijalnih ispitanika u svakoj zemlji. Pitanja su prilagođena s obzirom na pilot. Uz pregled literature i sondažno istraživanje, valjanost sadržaja instrumenta provjerena je uz pomoć stručnjaka iz triju područja koji su dali povratnu informaciju o upitniku i o tome koliko dobro pitanja mjere konstrukt. Objektivnost je osigurana odabirom pitanja zatvorenoga tipa. S obzirom na istraživačka pitanja, uglavnom su se koristile deskriptivne procedure (frekvencija, postotak, srednja vrijednost, standardna devijacija) i statistički testovi (Pearsonov hi-kvadrat test s prilagođenim standardnim ostatkom) koristeći se statističkim paketom SPSS, inačica 21.0.

\section{Rezultati}

Prikaz 1 prikazuje glavne razloge zbog kojih se slovenski i indijski učitelji odlučuju za učiteljsku profesiju. Većina učitelja u Sloveniji izabrala je tu profesiju zbog toga jer vole raditi s djecom $(50,8 \%)$, a taj je razlog odabralo tek $29 \%$ indijskih učitelja engleskoga jezika. Oni su se uglavnom opredijelili za karijeru učitelja jer se učiteljstvo smatra uglednim poslom (32,6\%), što je odabralo tek $6,1 \%$ slovenskih učitelja. Slično, učitelji ispitanici iz Indije izabrali su učiteljsku profesiju jer je smatraju dobrom profesijom (24,6\%), a samo 3,9\% slovenskih učitelja engleskoga jezika izabralo je taj razlog. $14,5 \%$ slovenskih i $4,2 \%$ indijska učitelja u ovoj anketi odlučilo je postati 
učiteljima jer ta profesija nudi siguran posao. Svi ostali razlozi imaju malen postotak u obje zemlje (npr. imate duge praznike: 3\% u Sloveniji i 1\% u Indiji, dobra plaća: 0,5\% u Sloveniji i 1,5\% u Indiji, postoji dobra prilika za promaknućem: 5\% u Sloveniji i 0,2\% u Indiji; kratak radni dan: 2,2\% u Sloveniji i 2,6\% u Indiji; postoji dobra mogućnost za dobivanje posla: 7,3\% u Sloveniji i 1,3\% u Indiji; obrazovanje za učitelja bilo je lako: $1,8 \%$ u Sloveniji i 0,5\% u Indiji, netko mi je preporučio učiteljsku profesiju: 3,9\% u Sloveniji i 0,5\% u Indiji). Vidimo da se učitelji u Indiji i Sloveniji razlikuju u odabiru razloga zbog kojega su se odlučili za učiteljsku profesiju. Daljnje analize pokazale su da je većina tih razlika statistički značajna.

\section{Prikaz 1}

\section{Tablica 1}

Prikaz 2 prikazuje uobičajene aktivnosti kojima se učitelji engleskoga jezika koriste u svojim razredima. Te su aktivnosti klasificirali prema učestalosti korištenja (5 svaki sat, 4 - često, 3 - ponekad, 2 - rijetko, 1 - nikada).

\section{Prikaz 2}

Neke od aktivnosti koje prevladavaju u nastavi engleskoga jezika u Indiji su vježbe pravopisa, vježbe gramatike, diktat, učenje riječi napamet, prepisivanje s ploče. Aktivnosti koje su često prisutne u poučavanju engleskoga u slovenskim razredima su slušanje audiozapisa, prepisivanje s ploče, pjevanje, igranje uloga, igre, ponavljanje za učiteljem, grupni rad i dramske aktivnosti. Glavna razlika između Indije i Slovenije prikazana je u tim aktivnostima; dok se ispitanici učitelji engleskoga jezika u Indiji uglavnom usredotočuju na vještine čitanja i pisanja, učitelji engleskoga u Sloveniji usredotočuju se u svojoj nastavi na razvoj vještine slušanja i govorenja. Međutim, ispitanici iz Indije često se koriste kreativnim aktivnosti pisanja koje se u Sloveniji u nastavi koriste tek povremeno.

\section{Prikaz 3}

Prikaz 3 prikazuje koje vještine učitelji u obje zemlje smatraju najvažnijima za razvijanje vještina u poučavanju engleskoga jezika u nižim razredima. Učitelji su klasificirali vještine (slušanje, govorenje, čitanje, pisanje, vokabular i gramatika) prema važnosti od 1 do 6 ( 1 - najvažnije, 6 - najmanje važno). Može se vidjeti da slovenski učitelji smatraju da je govorenje vještina koju treba najviše uvježbavati, a da je gramatika jedna od vještina koju treba najmanje uvježbavati. Anketirani učitelji u Indiji slažu se u vještini koju treba najmanje uvježbavati (gramatika), ali su odabrali razvoje vještine slušanja kao najvažniju vještinu. Slovenski učitelji više pozornosti pridaju razvoju vokabulara u usporedbi s kolegama u Indiji. Učitelji u obje zemlje smjestili su vještine čitanja i pisanja na istu razinu (čitanje je doseglo razinu srednje važnosti, a razvoj vještine pisanja ne smatraju toliko važnim u nastavi engleskoga jezika u primarnom obrazovanju). Tablica 2 prikazuje statističke podatke za jezične 
vještine koje su indijski i slovenski učitelji odabrali kao najvažnije vještine koje njihovi učenici moraju razviti.

\section{Tablica 2}

\section{Prikaz 4}

Prikaz 4 pokazuje neke čimbenike koje učitelji smatraju da bi mogli poboljšati nastavu engleskoga jezika. Učitelje smo pitali da poredaju po važnosti osam čimbenika (1 - najvažnije, odnosno najviše bi poboljšao učenje i poučavanje u mojem okruženju i 8 - najmanje važno, odnosno najmanje bi poboljšalo učenje i poučavanje u mojem okruženju). Učitelji su mogli birati od ponuđenih čimbenika: manji razredi, početak poučavanja engleskoga u ranijoj dobi, više sati engleskoga u tjednu, dodatno obrazovanje u području metodike jezika, bolji pristup novim tehnologijama, bolji pristup materijalima poput knjiga i materijala, manje testiranja i ispita te poboljšanje vlastite razine znanja engleskoga jezika. I ovdje se među dvije spomenute zemlje mogu uočiti mnoge razlike. Slovenski učitelji (u usporedbi s indijskim učiteljima) vrlo visoko su procijenili važnost početka poučavanja engleskoga jezika u ranijoj dobi te dodatno obrazovanje u području metodike jezika. Indijski učitelji, u usporedbi sa slovenskim, visoko su procijenili važnost pristupa novim tehnologijama i manjem broju testova i ispita. Bolji pristup izvorima (npr. knjige i materijali) dostigao je visoku razinu važnosti u obje zemlje.

\section{Tablica 3}

\section{Rasprava}

U vezi s prvim istraživačkim pitanjem (Postoji li razlika među indijskim i slovenskim učiteljima s obzirom na razloge zbog kojih su odabrali učiteljsku profesiju?) možemo vidjeti da učitelji u obje zemlje odabiru učiteljsku profesiju zbog različitih razloga. Slovenski učitelji uglavnom odabiru tu profesiju jer vole djecu, a indijski zbog toga jer je to ugledan posao. To je potvrđeno i u drugim dokumentima poput Ministry of Human Resource Development (n.d.) (Hrv. Ministarstva razvoja ljudskih potencijala) gdje je potvrđeno da je učiteljska profesija u Indiji vrlo cijenjena. To je mogući razlog zbog kojega se sve više indijskih studenata odlučuje za učiteljsku profesiju i porasta privatnih institucija koje nude potvrde o izobrazbi nastavnika (Rhines Cheney, Brown Ruzzi i Muralidharan, 2005). U studiji koju je proveo Emery (2012), koja je provedena na 2500 učitelja engleskoga jezika u primarnom obrazovanju iz različitih krajeva svijeta, većina učitelja (77\%) odabrala je isti razlog kao i slovenski učitelji u našem uzorku, odnosno zato što vole djecu, a njih $29 \%$ odabralo je: zato što je to cijenjen posao. Očigledno su to dva najčešća razloga i u drugim dijelovima svijeta. Zanimljivo je opažanje da je glavni razlog koji su odabrali indijski učitelji ekstrinzične prirode, a glavni razlog koji su odabrali slovenski učitelji intrinzične prirode. Bernaus, Wilson i Gardner (2009) u rezultatima svojega istraživanja smatraju da je motivacija učitelja povezana s korištenjem strategija motivacije koje su opet 
povezane s motivacijom studenata i uspjehom u engleskom jeziku. Prema tome, bilo koja promjena u obrazovnom sustavu koja promiče više razine motivacije učitelja trebala bi rezultirati unapređenjem razine obrazovanja učenika. U skladu s time učitelji koji su više intrinzično motivirani imaju jači poriv i autonomiju u svome poslu, pa i u odabiru nastavnih aktivnosti. Stoga se prva hipoteza može potvrditi, odnosno indijski i slovenski učitelji engleskoga jezika u primarnom obrazovanju značajno se razlikuju u razlozima odabira učiteljske profesije.

Drugo istraživačko pitanje ispitivalo je razlike u vrstama i učestalosti aktivnosti kojima se učitelji koriste u nastavi engleskoga jezika. Mnoge razlike pojavljuju se kod primjene aktivnosti, a jedna od izrazitih jest razlika u fokusu na aktivnosti govorenja i slušanja u nastavi engleskoga jezika u Sloveniji, zatim aktivnosti čitanja i pisanja (s težištem na pravopis, diktat i gramatičke vježbe) u nastavi engleskoga jezika u Indiji. Kurikul za engleski jezik u primarnom obrazovanju u Sloveniji potiče razvoj vještine slušanja i govorenja u prvim godinama učenja stranoga jezika. Kao što je vidljivo i iz ove ankete, učitelji se drže izvedbenoga plana u tome smislu (Učni načrti za angleščino, 2016). Mukund Ghatage (2009) izvješćuje da se učitelje iz indijske pokrajine Maharashtra potiče, vladinim dokumentima, da se usredotoče na vještine slušanja i govorenja u primarnom obrazovanju, ali u isto je vrijeme primijećeno da učitelji u ruralnim područjima nemaju pristup audiomaterijalima i da se učitelji često ne koriste engleskim jezikom u nastavi. I jedno i drugo dovodi do nedovoljno razvijene vještine slušanja i vještine govorenja. Unatoč činjenici da se učitelji usredotočuju na razvoj vještina čitanja i pisanja, Kunnan i Matthew (2006), kao i Azam i Kingdon (2013) vrednovali su učeničke vještine čitanja i pisanja u Indiji te su primijetili da one nisu razvijene u mjeri u kojoj su trebale biti. Banerji i Bobde (2013) saželi su ASER izvješće (2013) ustvrdivši da manje od polovine učenika u petom razredu može pročitati jednostavne riječi na engleskome jeziku a $40 \%$ onih koji mogu pročitati riječi ne znaju njihovo značenje. Istraživanja također pokazuju da se učitelji u Indiji usredotočuju na razvijanje gramatike unatoč preporukama nadležnih u kojima se naglaša da se poučavanje treba orijentirati više na značenje nego na gramatiku (NCERT, 2006). U prošlosti je takva situacija bila slična i u Sloveniji, međutim, posljednji plan i program za Engleski jezik jako potiče komunikacijsko poučavanje jezika (Skela, 2013). Garton, Copland i Burns (2011) u svojoj anketi o praksi u nastavi engleskoga jezika u primarnome obrazovanju u cijelome svijetu (4.696 učitelja iz 144 zemlje) izvijestili su o pet najučestalijih aktivnosti u razredu: ponavljanje za učiteljem, slušanje audiomaterijala, učeničko čitanje naglas, igranje igara i pjevanje pjesama. $U$ ovome istraživanju te su aktivnosti više karakteristične za Sloveniju nego za Indiju. Druga hipoteza, odnosno „Postoje razlike u vrstama i učestalosti aktivnosti kojima se koriste učitelji engleskoga jezika u primarnome obrazovanju u Sloveniji i Indiji” može se potvrditi.

Kod trećeg istraživačkog pitanja (Postoje li razlike u stavovima učitelja u vezi $s$ razvojem jezičnih vještina engleskoga jezika kod učenika u Sloveniji i Indiji?) 
istraživanje je pokazalo neke razlike u percepciji učitelja o važnosti vještina. Dok slovenski učitelji smatraju da su razvoj govornih vještina engleskoga jezika (srednja vrijednost: 1,63$)$ i vokabular $(3,03)$ najvažniji, indijski učitelji smatraju da su razvoj vještine slušanja (srednja vrijednost: 2,79$)$ i vještine govorenja $(3,39)$ najvažnije. To je interesantno s obzirom na to da aktivnosti kojima se koriste u poučavanju (vidi Sliku 2) prikazuju tendenciju prema razvoju vještina čitanja i pisanja. Garton, Copland i Burnsovo istraživanje (2011) pokazalo je slične rezultate. Diljem svijeta učitelji engleskoga jezika u primarnom obrazovanju smatraju da je govorenje $(M=2,4)$ najvažnija vještina koju učenici moraju razviti, a prate je vještina slušanja $(M=3,1)$ i vokabular $(M=3,6)$. Usporedivo s tim istraživanjem, gramatiku i pisanje doživljavaju kao najmanje važne vještine koje se trebaju razviti u poučavanju na primarnoj razini. Treća hipoteza, „Učitelji u Indiji i Sloveniji razlikuju se u stavovima prema razvoju jezičnih vještina učenika engleskoga jezika" može se parcijalno dokazati. Učitelji se uglavnom razlikuju u percepciji važnosti razvoja vokabulara i vještine govorenja, no njihovi pogledi na razvoj gramatike, vještine čitanja i vještine pisanja su prilično slični.

Kod četvrtoga istraživačkoga pitanja u kojem se tražilo da učitelji navedu čimbenike koji bi mogli poboljšati poučavanje jezika u svojim zemljama, slovenski učitelji izabrali su početak poučavanja engleskoga jezika u ranijoj dobi kao važan čimbenik. To možemo pripisati činjenici da se u vrijeme provedbe istraživanja engleski jezik poučavao od četvrtoga razreda (sada poučavanje engleskoga započinje u drugom razredu) pa su učitelji to percipirali kao važan čimbenik. U Indiji to nije važan čimbenik s obzirom na to da se engleski jezik uči od prvoga razreda. Zbog činjenice da se engleski poučava u ranijoj dobi, što nalaže različitu paradigmu poučavanja u usporedbi s poučavanjem starijih učenika, slovenski učitelji izabrali su dodatno obrazovanje u metodici poučavanja jezika kao čimbenik koji bi najviše doprinio boljem poučavanju i učenju engleskoga jezika u Sloveniji. Poučavanje stranoga jezika u prvim godinama primarnoga obrazovanja traži autonomnog učitelja koji može odabrati i razviti svoje materijale za poučavanje ne oslanjajući se na udžbenik što se, zapravo, destimulira u prvim godinama učenja stranoga jezika u slovenskim školama. Slično tvrdi i Enever (2015) da unatoč nedostatku materijala vješti učitelji mogu ostvariti visokokvalitetnu nastavu stvarajući svoje materijala i prilagođavajući materijale koje posjeduju.

Većina čimbenika koji bi mogli poboljšati poučavanje i učenje stranih jezika u Indiji razlikuje se od onih u Sloveniji. Jedini čimbenik koji je vrlo sličan jest bolji pristup resursima, koji indijski učitelji smatraju najvažnijim čimbenikom. Kao što pokazuju rezultati drugih istraživanja (vidi Kapur, 2009; Matthew i Pani, 2009), očit je nedostatak materijala $u$ indijskim razredima, što autori smatraju razlogom smanjene kvalitete poučavanja. Ispitanici iz Indije odabrali su poboljšanje vlastite razine znanja engleskoga jezika kao drugi najvažniji čimbenik. Mnogi izvori (Graddol, 2010; Kapur, 2009; Mukund Ghatage, 2009, i ostali) navode da indijskim učiteljima engleskoga jezika nedostaje tečnost $\mathrm{u}$ engleskome jeziku te da im je opće znanje slabo. 
Navodno su učitelji svjesni te činjenice i njezine važnosti za poučavanje stranih jezika. Indijski učitelji odabrali su smanjenje testova $i$ ispita kao treći najvažniji čimbenik koji dolazi od činjenice da postoji pritisak na učitelje u vezi s postupkom vrednovanja i rezultatima koji učenici postižu u indijskim razredima. Četvrti čimbenik koji su odabrali su manji razredi, što je i razumljivo s obzirom na to da je prosječan broj učenika prema podacima Svjetske banke 35, ali može premašiti i 90 učenika po razredu (odnos učenik-učitelj u primarnom obrazovanju, n.d.). Rezultati istraživanja koje su proveli Garton, Copland i Burns (2011) na 4696 učitelja iz 144 zemlje pokazalo je da učitelji u primarnom obrazovanju biraju obrazovanje u metodici poučavanja jezika, manje razrede i više sati tjedno engleskoga jezika kao čimbenike koji bi mogli najviše doprinijeti boljem poučavanju engleskoga jezika u njihovim zemljama. Neki od tih čimbenika preklapaju se s rezultatima našega istraživanja, osim čimbenika više sati engleskoga tjedno, čemu indijski i slovenski učitelji pripisuju vrlo nisku razinu važnosti za poboljšanje kvalitete poučavanja i učenja stranoga jezika. Posljednja hipoteza, „Učitelji u Indiji i Sloveniji razlikuju se u stavovima o promjenama koje su potrebne za poboljšanje razine poučavanja i učenja engleskoga jezika u svojim zemljama" može se potvrditi. Većina se promjena potrebnih za poboljšanje učenja i poučavanja razlikuju.

\section{Zaključci}

U provedenom istraživanju pokušale su se rasvijetliti percepcije učitelja engleskoga jezika u primarnom obrazovanju u dvije zemlje, Indiji i Sloveniji. Smatramo da dobiveni rezultati mogu pomoći učiteljima, nastavnicima - instruktorima i onima koji planiraju programe studija kod evaluacije postojećeg stanja poučavanja i učenja stranoga jezika, kao i u planiranju budućih programa za obrazovanje učitelja stranih jezika. Rezultati su ukazali na neke razlike između dvije skupine ispitanih učitelja, uglavnom kod odabira učiteljske profesije koju je većina slovenskih učitelja odabrala jer voli djecu (što se podudara s prijašnjim istraživanjem koje su proveli Garton, Copland i Burns, 2011) i indijskih učitelja koji su je odabrali jer je to ugledan posao. Činjenica da su razlozi slovenskih učitelja za odabir učiteljske profesije intrinzične prirode, a ispitanika indijskih učitelja ekstrinzične, može biti povezana s ostalim rezultatima istraživanja, poglavito kod razlika u aktivnostima koje se koriste u nastavi, u odabiru jezičnih vještina koje žele razviti kod svojih učenika i čimbenika za koje smatraju da bi poboljšali vlastito poučavanje. Međutim, također postoje i neke sličnosti među indijskim i slovenskim učiteljima u percepciji poučavanja stranoga jezika koje je istraživanje pokazalo, npr. odabir vještine govorenja, slušanja i vokabulara kao najvažnijih vještina koje učenici trebaju razviti kod učenja stranoga jezika, što se ponovno može povezati sa stavovima učitelja diljem svijeta (Garton, Copland i Burns, 2011). Slovenski i indijski učitelji također se slažu o važnosti čimbenika koji bi poboljšali poučavanje i učenje stranoga jezika u njihovim zemljama, a to je bolji pristup resursima.

Međutim, usporedba dviju zemalja donosi moguće zamke s obzirom na to da je engleski u Sloveniji strani jezik, a u Indiji ima status službenoga jezika. Učitelji u Indiji 
moraju biti dobro obrazovani kako bi udovoljili potrebama učenika koji žele imati visoku razinu znanja da bi poboljšali izglede u karijeri. Možda je to razlog zbog kojega su izabrali poboljšanje vlastite razine znanja engleskoga jezika kao drugu najvažniju promjenu koja bi doprinijela boljoj razini engleskoga jezika u svojoj zemlji. Vještine koje žele razviti kod svojih učenika (slušanje, govorenje i čitanje).

Prepoznajemo da uzorak ispitanika $u$ našem istraživanju nije reprezentativan $i$ stoga nije moguće generalizirati rezultate. Međutim, rezultati istraživanja mogu implicirati neke percepcije učitelja engleskoga jezika u primarnom obrazovanju. Drugo ograničenje ovoga istraživanja jest to što rezultati istraživanja izvješćuju o praksi koja se možda ne podudara uvijek sa stvarnim događanjima. Stoga bi daljnja istraživanja trebala uključivati i opažanja u razredu i dubinsku analizu dobivenih opažanja.

Hayes (2014, str. 2) tvrdi da je najvažniji čimbenik koji utječe na uspješnost u poučavanju engleskoga jezika u primarnom obrazovanju ,učitelj koji ima pozitivan stav prema engleskome jeziku i prema poučavanju jezika, što će utjecati na motivaciju učenika za učenjem, za uživanjem u nastavi engleskoga jezika i na kraju na njihov uspjeh". Daljnja istraživanja te teme potrebna su kako bi se istražile percepcije učitelja i načini poboljšanja obrazovanja učitelja, razine njihovih jezičnih vještina i metoda poučavanja, što će rezultirati višom razinom znanja stranoga jezika kod učenika i želji za cjeloživotnim učenjem jezikâ. 